\title{
Association between dietary intake and postlapa- roscopic cholecystectomic symptoms in patients with gallbladder disease
}

\author{
Yongju Shin ${ }^{1}$, Dongho $\mathrm{Choi}^{2}$, Kyeong Geun $\mathrm{Lee}^{2}$, Ho Soon $\mathrm{Choi}^{3}$, and Yongsoon Park ${ }^{1}$
}

\author{
${ }^{1}$ Department of Food and Nutrition, \\ Hanyang University College of \\ Human Ecology, Seoul; Departments \\ of ${ }^{2}$ Surgery and ${ }^{3}$ Internal Medicine, \\ Hanyang University College of \\ Medicine, Seoul, Korea
}

Received: July 12, 2016

Revised : October 5, 2016

Accepted: October 10, 2016

\section{Correspondence to}

Yongsoon Park, Ph.D.

Department of Food and Nutrition, Hanyang University, 222

Wangsimni-ro, Seongdong-gu,

Seoul 04763, Korea

Tel: +82-2-2220-1205

Fax: $+82-2-2292-1226$

E-mail:yongsoon@hanyang.ac.kr
Background/Aims: After cholecystectomy, patients have reported postcholecystectomic syndromes such as abdominal symptoms, dyspepsia, and diarrhea, which suggest a relationship between cholecystectomic symptoms and diet, although the details of this association remain unclear. The present study investigated the hypothesis that dietary intake of nutrients and foods was significantly associated with postcholecystectomic syndromes.

Methods: Gallstone patients ( $\mathrm{n}=59)$ who underwent laparoscopic cholecystectomy were enrolled, and dietary intake and clinical parameters were assessed immediately postcholecystectomy and 3 months later.

Results: There were no significant differences in biochemical measurements or characteristics between symptomatic and asymptomatic patients. Immediately postcholecystectomy, there were no significant differences in consumption of nutrients or foods between symptomatic and asymptomatic patients. However, 3 months after cholecystectomy, symptomatic patients consumed more animal protein, cholesterol, and eggs, and fewer vegetables than did asymptomatic patients. Multivariable-adjusted regression analyses also indicated that the risk for symptoms was positively associated with intake of animal protein, cholesterol, and eggs, but negatively associated with intake of vegetables after adjusting for confounders. In addition, symptomatic patients consumed more bread-based breakfast foods, while asymptomatic patients consumed more rice.

Conclusions: Postcholecystectomic syndromes were positively associated with intake of cholesterol, animal protein, and eggs, and negatively associated with intake of vegetables, suggesting that diet was plays a role in postcholecystectomic syndromes.

Keywords: Diet; Gallstone; Postcholecystectomy syndrome; Follow-up studies

\section{INTRODUCTION}

Laparoscopic cholecystectomy is an effective treatment for symptomatic cholelithiasis with minimal risk [1]. However, some patients who undergo cholecystectomy report postcholecystectomic syndromes, defined as the recurrence of symptoms similar to those experienced before the cholecystectomy, such as abdominal symptoms, dyspepsia and diarrhea [2].

The absence of the gallbladder after a cholecystectomy was reported to cause rapid enterohepatic recycling, an increase in the secretion and a decrease in the reabsorp- 
tion of bile acid, and a shortened colonic transit time $[3,4]$. Some patients who underwent cholecystectomy experienced diarrhea, which could be associated with the malabsorption of bile acid [5]. After cholecystectomy, patients are at an increased risk for duodenogastric reflux, which causes dyspepsia [6,7]. In addition, abdominal pain and irritable bowel syndrome were reported in patients after cholecystectomy; these symptoms could be associated with sphincter of Oddi dysfunction $[8,9]$.

It has been suggested that postcholecystectomic syndromes are related to diet, due to changes in bile acid metabolism [3] and duodenogastric reflux [7]. Taiwanese patients who did not follow instructions to maintain a low-fat diet experienced more diarrhea, both 1 week and 3 months after cholecystectomy [10]. A high-fat diet has been shown to increase fecal bile acid [11], and diarrhea can be caused by the increased passage of bile acids into the colon [12]. In addition, after laparoscopic cholecystectomy, some patients reported troublesome food intolerance, particularly to fatty foods $[13,14]$. Intolerance to fatty foods appears frequently in patients with dyspepsia, since fatty foods could delay gastric emptying $[15,16]$.

Previous studies have focused only on the relationship between a high-fat diet and postcholecystectomic syndromes [10,13,14], and no other nutrients or foods. Therefore, the present study investigated the hypothesis that dietary intake of nutrients and foods was significantly associated with postcholecystectomic syndromes.

\section{METHODS}

\section{Patients}

Gallstone patients $(\mathrm{n}=59)$ who underwent laparoscopic cholecystectomy at the general surgery clinic, Hanyang University Seoul Hospital, Seoul, Korea from April 2014 to May 2015 were enrolled in this study. Patients were asked if they had symptoms, such as abdominal pain, dyspepsia, functional constipation, and diarrhea immediately postlaparoscopic cholecystectomy and 3 months later. This study was performed in accordance with the Declaration of Helsinki. All procedures were approved by the Institutional Review Board of Hanyang University (HYI-14-0o1-2), and written informed consent was obtained from all patients.

\section{Data collection}

The following information was obtained from patients by trained interviewers: age, sex, family history of gallstone disease, medical and medication history, previous experience with weight control, exercise, smoking status, and alcohol and supplement consumption. Height, weight, and waist circumference were measured, and body mass index (BMI, $\mathrm{kg} / \mathrm{m}^{2}$ ) was calculated. Information regarding fatty liver and the diameter of the common bile duct were obtained from medical records and pathology reports. All patients underwent ultrasound at the time of the operation and 3 months later. Ultrasound was performed with an $\mathrm{iU}_{22}$ (Philips Ultrasound, Bothell, WA, USA) or a EUB-7500 (Hitachi, Tokyo, Japan) equipped with a 5-MHz convex transducer.

\section{Biochemical data}

Biochemical parameters tests, including white blood count (WBC), hemoglobin (Hb), hematocrit (Hct), and platelet (PLT), were measured by a Sysmex XE-2100 (Sysmex, Kobe, Japan). Total protein (TP), albumin (ALB), fasting blood sugar (FBS), creatinine (Cr), blood urea nitrogen (BUN), aspartate aminotransferase (AST), alkaline phosphatase (ALP), triglyceride (TG), total cholesterol (TC), low density lipoprotein cholesterol (LDL-C), and high density lipoprotein cholesterol (HDL-C) were measured by a Hitachi 7600 automatic analyzer (Hitachi).

\section{Dietary assessment}

After laparoscopic cholecystectomy, dietary intake was assessed using a semiquantitative food frequency questionnaire of 63 food items commonly consumed by Korean national health and examination survey [17]. Patients were asked about the frequency of intake for each food during the previous year, on average. Frequency of food intake was classified into 10 categories: 1,2 , or 3 times per day; 4 to 6 times per week; 2 to 3 times per week; once per week; 2 to 3 times per month; once per month; 6 to 11 times per year; and never or seldom. Three months after laparoscopic cholecystectomy, dietary intake was assessed using 24-hour recall, including food description, time of intake, amount of food and location where food was eaten. Dietary intake was analyzed using Canpro 4.0 (Korean Nutrition Society, Seoul, Korea). 


\section{Statistical analysis}

Data were expressed as mean \pm standard deviation, and a $p$ value less than 0.05 was considered statistically significant. All data were analyzed using SPSS version 21.0 (IBM Co., Armonk, NY, USA). Categorical variables were analyzed using the chi-square test, and continuous variables were analyzed using independent $t$ tests. Odds ratios and 95\% confidence intervals were obtained using multivariable logistic regression analyses in order to determine the associations of daily nutrients and foods intake according to the presence of symptoms after adjusting for energy intake and a medical history of digestive diseases postlaparoscopic cholecystectomy, and energy intake and exercise frequency 3 months after laparoscopic cholecystectomy.

\section{RESULTS}

\section{Characteristics of symptomatic and asymptomatic patients}

After laparoscopic cholecystectomy, symptomatic patients had a more extensive medical history of digestive disease than did asymptomatic patients (Table 1 ). Symptomatic patients also exercised less $(3$ to 4 times per week) than did asymptomatic patients ( 5 to 6 times per week) 3 months after laparoscopic cholecystectomy. Comparing symptomatic and asymptomatic patients, there were no significant differences in age, sex, BMI, waist circumference, family history of gallstone disease, medications, previous experiences of weight control, smoking, drinking, use of supplements, the presence of fatty liver, or the diameter of the common bile duct (Table 1). At postlaparoscopic cholecystectomy and 3 months after laparoscopic cholecystectomy, blood pa-

Table 1. Characteristics of asymptomatic and symptomatic patients immediately postlaparoscopic cholecystectomy and 3 months after laparoscopic cholecystectomy

\begin{tabular}{|c|c|c|c|c|c|c|}
\hline \multirow{2}{*}{ Characteristic } & \multicolumn{3}{|c|}{$\begin{array}{l}\text { Postlaparoscopic } \\
\text { cholecystectomy }\end{array}$} & \multicolumn{3}{|c|}{$\begin{array}{l}\text { Three months after laparoscopic } \\
\text { cholecystectomy }\end{array}$} \\
\hline & $\begin{array}{l}\text { Asymptomatic } \\
(\mathrm{n}=24)\end{array}$ & $\begin{array}{l}\text { Symptomatic } \\
(\mathrm{n}=35)\end{array}$ & $p$ value & $\begin{array}{l}\text { Asymptomatic } \\
(\mathrm{n}=32)\end{array}$ & $\begin{array}{l}\text { Symptomatic } \\
(\mathrm{n}=27)\end{array}$ & $p$ value \\
\hline Age, yr & $47.54 \pm 12.34$ & $50.31 \pm 14.92$ & 0.456 & $51.03 \pm 11.56$ & $47.67 \pm 16.17$ & 0.371 \\
\hline Female sex & $11(45.8)$ & $18(51.4)$ & 0.673 & $14(43.8)$ & $15(55 \cdot 6)$ & 0.366 \\
\hline Body mass index, $\mathrm{kg} / \mathrm{m}^{2}$ & $25.73 \pm 4.44$ & $25.02 \pm 3.04$ & 0.471 & $25.65 \pm 3.46$ & $25.13 \pm 3.88$ & 0.585 \\
\hline Waist circumference, $\mathrm{cm}$ & $92.33 \pm 11.70$ & $91.67 \pm 11.31$ & 0.828 & $88.05 \pm 9.88$ & $87.56 \pm 9.74$ & 0.849 \\
\hline Family history of gallstones & $3(12.5)$ & $6(17.1)$ & 0.626 & $2(6.3)$ & $5(18.5)$ & 0.147 \\
\hline $\begin{array}{l}\text { Medical history of digestive } \\
\text { system disease }\end{array}$ & $2(8.3)$ & $11(31.4)$ & 0.036 & $8(25.0)$ & $8(29 \cdot 6)$ & 0.690 \\
\hline Medication & $13(54.2)$ & $20(57.1)$ & 0.821 & $15(46.9)$ & $10(37.0)$ & 0.446 \\
\hline Dieting for weight control & $8(33 \cdot 3)$ & $16(45 \cdot 7)$ & 0.342 & $2(6.3)$ & $3(11.1)$ & 0.504 \\
\hline Exercise $^{\mathrm{a}}$ & $8(33 \cdot 3)$ & $18(51.4)$ & 0.169 & $14(43.8)$ & $16(59 \cdot 3)$ & 0.235 \\
\hline 1-2 times/wk & $4(50.0)$ & $5(27.8)$ & & $4(28.6)$ & $5(31.3)$ & \\
\hline 3-4 times/wk & $2(25.0)$ & $8(44 \cdot 4)$ & 0.502 & $1(7.1)$ & $8(50.0)$ & 0.014 \\
\hline$\geq 5-6$ times/wk & $2(25.0)$ & $5(27.8)$ & & $9(64 \cdot 3)$ & $3(18.8)$ & \\
\hline Smoking & $3(12.5)$ & $3(8.6)$ & 0.624 & $4(12.5)$ & $3(11.1)$ & 0.869 \\
\hline Drinking & $17(70.8)$ & $21(60.0)$ & 0.393 & $18(56.3)$ & $12(44 \cdot 4)$ & 0.366 \\
\hline Fatty liver & $14(58.3)$ & $15(42.9)$ & 0.243 & $19(59 \cdot 4)$ & $13(50.0)$ & 0.475 \\
\hline CBD diameter, $\mathrm{mm}$ & $4.35 \pm 1.22$ & $3.90 \pm 1.26$ & 0.185 & $4.91 \pm 2.34$ & $4.66 \pm 1.95$ & 0.663 \\
\hline Change in CBD diameter, $\mathrm{mm}$ & - & - & - & $0.95 \pm 2.19$ & $0.40 \pm 2.48$ & 0.367 \\
\hline
\end{tabular}

Values are presented as mean \pm SD or number (\%). $p$ values were determined by independent $t$ test for continuous variables, and the chi-square test for the categorical variables between symptomatic and asymptomatic patients.

CBD, common bile duct.

${ }^{\mathrm{a}} \geq 30$ Minutes in one session. 
rameters, such as WBC, Hb, Hct, PLT, TP, ALB, FBS, Cr, BUN, AST, ALP, TG, TC, HDL-C, and LDL-C were not significantly different between symptomatic and asymptomatic patients (data not shown) (Supplementary

Table 2. Daily intake of nutrients and foods between asymptomatic and symptomatic patients 3 months after laparoscopic cholecystectomy

\begin{tabular}{|c|c|c|c|}
\hline Variable & Asymptomatic $(\mathrm{n}=32)$ & Symptomatic $(n=27)$ & $p$ value \\
\hline Energy, kcal & $1,716.97 \pm 474.02$ & $1,616.83 \pm 657.49$ & 0.500 \\
\hline Carbohydrate, g/1,00o kcal & $155.07 \pm 32.27$ & $146.01 \pm 36.22$ & 0.314 \\
\hline Lipid, g/1,00o kcal & $25.89 \pm 10.84$ & $25.98 \pm 9.52$ & 0.974 \\
\hline Protein, g/1,ooo kcal & $36.71 \pm 8.60$ & $42.85 \pm 14.21$ & 0.056 \\
\hline Plant protein, g/1,ooo kcal & $21.30 \pm 6.63$ & $19.70 \pm 5.13$ & 0.312 \\
\hline Animal protein, g/1,ooo kcal & $15.41 \pm 10.07$ & $23.15 \pm 16.00$ & 0.035 \\
\hline Fiber, g/1,00o kcal & $14.03 \pm 7.27$ & $11.93 \pm 4.38$ & 0.194 \\
\hline Cholesterol, mg/1,00o kcal & $136.51 \pm 112.55$ & $219.39 \pm 153.25$ & 0.020 \\
\hline Grain, g & $272.28 \pm 156.76$ & $237.90 \pm 183.00$ & 0.440 \\
\hline Potato, $g$ & $36.71 \pm 61.25$ & $32.73 \pm 66.27$ & 0.812 \\
\hline Vegetable, g & $324.12 \pm 203.49$ & $212.663 \pm 134.13$ & 0.018 \\
\hline Fruit, g & $159.20 \pm 130.76$ & $221.71 \pm 271.71$ & 0.253 \\
\hline Meat, g & $63.09 \pm 77.03$ & $91.03 \pm 119.03$ & 0.300 \\
\hline Egg, g & $12.17 \pm 19.17$ & $35 \cdot 91 \pm 44.42$ & 0.014 \\
\hline Fish and seafood, $g$ & $80.14 \pm 132.95$ & $63.82 \pm 83.40$ & 0.583 \\
\hline Dairy product, g & $65.79 \pm 92.73$ & $79.61 \pm 117.34$ & 0.615 \\
\hline
\end{tabular}

Values are presented as mean \pm SD. $p$ values were determined by independent $t$ test.

Table 3. Dietary habits between asymptomatic and symptomatic patients 3 months after laparoscopic cholecystectomy

\begin{tabular}{|c|c|c|c|}
\hline Variable & Asymptomatic $(\mathrm{n}=32)$ & Symptomatic $(n=27)$ & $p$ value \\
\hline Breakfast consumer & $31(96.9)$ & $23(85.2)$ & 0.108 \\
\hline Rice & $25(80.6)$ & $12(52.2)$ & \\
\hline Potato & o & $2(8.7)$ & \\
\hline Bread & 0 & $5(21.7)$ & 0.015 \\
\hline Dairy & $3(9.7)$ & $2(8.7)$ & \\
\hline Fruit and vegetable & $3(9.7)$ & $2(8.7)$ & \\
\hline Food preferred & $5(15.6)$ & $7(25.9)$ & 0.327 \\
\hline Potato & 0 & $1(14 \cdot 3)$ & \\
\hline Fruit and vegetable & $5(100.0)$ & $5(71.4)$ & 1.000 \\
\hline Seafood & 0 & $1(14 \cdot 3)$ & \\
\hline Food avoided & $10(31.3)$ & $16(59 \cdot 3)$ & 0.031 \\
\hline Meat & $3(30.0)$ & $4(25.0)$ & \\
\hline Oily food & $5(50.0)$ & $9(56.3)$ & \\
\hline Seafood & 0 & $1(6.3)$ & 0.388 \\
\hline Alcohol & $2(20.0)$ & $\mathrm{O}$ & \\
\hline Other & 0 & $2(12.5)$ & \\
\hline
\end{tabular}

Values are presented as number (\%). $p$ values were determinate by chi-square test for the categorical variables between symptomatic and asymptomatic patients. 
Table 1).

\section{Dietary intake of symptomatic and asymptomatic patients}

Immediately postlaparoscopic cholecystectomy, there were no significant differences in the consumption of nutrients or foods between symptomatic and asymptomatic patients (data not shown)(Supplementary Tables 2 and 3). However, 3 months after laparoscopic cholecystectomy, symptomatic patients consumed more animal protein, cholesterol, and eggs, and fewer vegetables than did asymptomatic patients (Table 2). There were no significant differences in consumption of vitamins, minerals, or other foods between symptomatic and asymptomatic patients 3 months after laparoscopic cholecystectomy (data not shown) (Supplementary Table 4). In addition, for breakfast, symptomatic patients consumed more bread, while asymptomatic patients consumed more rice (Table 3). Symptomatic patients avoided more foods compared to asymptomatic patients. There were no significant differences in food preferences or avoided foods between symptomatic and asymptomatic patients.

\section{Association between the risk for occurrence of symptoms and dietary intake}

There was no significant association between the risk for occurrence of symptoms and dietary intake at postlaparoscopic cholecystectomy (data not shown) (Supplementary Tables 5 and 6). However, at 3 months after laparoscopic cholecystectomy, multivariable-adjusted regression analysis found that the risk for occurrence of symptoms was positively associated with intake of animal protein, cholesterol, and eggs, while it was negatively associated with intake of vegetables, after adjusting for energy intake and exercise frequency (Table 4). There were no significant associations between the risk of symptoms and intake of any other nutrients or foods at 3 months after laparoscopic cholecystectomy (data not shown) (Supplementary Tables 7 and 8).

Table 4. Association between dietary intake and the risk of symptoms 3 months after laparoscopic cholecystectomy by multivariable logistic regression analysis

\begin{tabular}{|c|c|c|c|c|}
\hline \multirow{2}{*}{ Variable } & \multicolumn{3}{|c|}{ Quartile of dietary intake } & \multirow{2}{*}{$p$ for trend ${ }^{a}$} \\
\hline & Q1 & Q2 & Q3 & \\
\hline Animal protein, $g$ & & & & 0.038 \\
\hline Number of S/A & $7 / 11$ & $6 / 12$ & $14 / 9$ & \\
\hline Cut-off & $\leq 15.6$ & $15.6<$ to $\leq 37.0$ & $>37.0$ & \\
\hline OR $(95 \% \mathrm{CI})^{\mathrm{b}}$ & 1 & $0.937(0.19-4.68)$ & $4.411(0.92-21.25)$ & \\
\hline Cholesterol, mg & & & & 0.041 \\
\hline Number of S/A & $5 / 11$ & $6 / 11$ & $16 / 10$ & \\
\hline Cut-off & $\leq 133.4$ & $133.4<$ to $\leq 251.6$ & $>251.6$ & \\
\hline OR $(95 \% \mathrm{CI})$ & 1 & $1.497(0.30-7.51)$ & $4.937(1.04-23.48)^{c}$ & \\
\hline Vegetable, g & & & & 0.022 \\
\hline Number of S/A & $16 / 10$ & $8 / 11$ & $3 / 11$ & \\
\hline Cut-off & $\leq 206.6$ & $206.6<$ to $\leq 385.7$ & $>385.7$ & \\
\hline OR (95\% CI) & 1 & $0.473(0.12-1.80)$ & $0.125(0.02-0.74)^{c}$ & \\
\hline Egg, g & & & & 0.023 \\
\hline Number of S/A & $8 / 18$ & $3 / 7$ & $16 / 7$ & \\
\hline Cut-off & $\leq 0$ & $0<$ to $\leq 20$ & $>20$ & \\
\hline OR (95\% CI) & 1 & $1.046(0.20-5.40)$ & $5.160(1.28-20.87)^{c}$ & \\
\hline
\end{tabular}

S/A, symptomatic patients/asymptomatic patients; OR, odds ratio; CI, confidence interval.

${ }^{a}$ Estimates of $p$ values for linear trend were based on linear scores derived from the medians of quartiles for intake of nutrients among asymptomatic patients.

${ }^{\mathrm{b}} \mathrm{OR}$ was adjusted for total energy intake and exercise frequency.

${ }^{c} p<0.05$ compared to the first quartile by logistic regression analysis. 


\section{DISCUSSION}

This study found that the risk of postcholecystectomic syndrome was positively associated with intake of animal protein, cholesterol, and eggs, and negatively associated with intake of vegetables in patients 3 months after laparoscopic cholecystectomy. In addition, 3 months after laparoscopic cholecystectomy, symptomatic patients consumed more bread for breakfast, while asymptomatic patients consumed more rice. However, there was no significant immediately postcholecystectomy association between postcholecystectomic syndrome and dietary intake.

Previous studies indicated that postcholecystectomic diarrhea was reported in patients who did not follow the low-fat diet guidelines [10] and who were intolerant of fatty foods [13]. Bile malabsorption has been shown to be associated with diarrhea in humans [18], and secretion of bile acid was dose dependently associated with fat intake in rats [19]. Thus, previous studies suggested that a high-fat diet could be associated with postcholecystectomic diarrhea, due to the changes in bile acid metabolism. However, the present study did not find a significant association between the intake of fat and the risk for postcholecystectomic syndromes. This inconsistency between the present and previous studies could be because patients in the present study did not consume a high-fat diet, as the average intake of fat was about $25 \mathrm{~g} /$ day and only $7 \%$ to $8 \%$ of the total energy intake.

Postcholecystectomy, patients reported symptoms of flatulent dyspepsia, which could be related to duodenogastric reflux and delayed gastric emptying [7,20]. Previously, food intolerance was observed in patients with postcholecystectomic dyspepsia, particularly, intolerance of eggs [14]. Pelletier et al. [21] also found that breakfast with bread and boiled eggs delayed gastric emptying in healthy volunteers, suggesting that the delayed gastric emptying by consumption of eggs could be positively associated with postcholecystectomic syndromes. Eggs could be a source of animal protein and cholesterol, which were also positively associated with the risk of postcholecystectomic syndromes in the present study. Intake of protein had been reported to slow gastric emptying in healthy volunteers [22], and dietary cholesterol increased fecal excretion of bile acids in rats [23]. Malabsorption of bile acids has been shown to cause postcholecystectomic diarrhea [5,24], since the absence of a gallbladder caused more rapid enterohepatic recycling of bile acids, increased bile acid secretion [3], and shortened colonic transit times [4]. Both the present and previous studies suggested that excretion and malabsorption of bile acids could be exacerbated by cholesterol intake in patients with cholecystectomies.

With the exception of the present study, there are no studies indicating any association between postcholecystectomic syndromes and vegetable intake. However, patients with functional gastrointestinal disorders, such as irritable bowel syndrome, consumed fewer vegetables than did healthy Taiwanese individuals [25]. In addition, dietary fiber has been shown to regulate the enterohepatic circulation of bile acids in patients with ileal resection [26]. In previous in vivo and in vitro studies, dietary fiber bound with bile acids, and reduced free bile acids in feces [27].

Patients with functional dyspepsia consumed more bread than rice [15], and bread had longer gastric emptying times compared with the rice pudding in healthy volunteers [28]. Gluten in meals has been shown to delay gastric emptying and cause gastrointestinal symptoms, such as bloating, abdominal pain and nausea in patients without celiac disease [29,30]. Similar with previous research, the present study found that symptomatic patients consumed more bread than rice, and symptoms could be due to the delayed gastric emptying of bread.

It has been suggested that cholecystectomy increases the risk for nonalcoholic fatty liver disease, due to increased hepatic triglyceride content [31-33]. In animal studies hepatic synthesis of bile acid was inhibited [34] and free fatty acid flux increased from adipose tissue to liver after a cholecystectomy [33,35]. In addition, a high level of fibroblast growth factor 19 was detected in surgically removed gallbladders from patients with gallbladder disease [36]. Fibroblast growth factor 19 has been shown to suppress the ability of insulin to stimulate hepatic fatty acid synthesis [37]. However, in the present study, there was no significant difference in the prevalence of fatty liver between asymptomatic and symptomatic patients at 3 months after a cholecystectomy.

After cholecystectomy, a slight dilatation of the common bile duct diameter commonly occurs [38], and is possibly associated with postcholecystectomic syndromes [39]. However, several previous studies reported 
inconsistent results regarding the association between dilatation of the common bile duct diameter and postcholecystectomic syndromes [38-40]. In the present study, the diameter of the common bile duct increased by less than $1 \mathrm{~mm}$, and was not significantly different between asymptomatic and symptomatic patients 3 months after cholecystectomy.

This study had several limitations. This study had small sample size, and 3 months of follow-up might have been an insufficient duration. In addition, dietary intake was assessed only once, which could be insufficient to determine the usual intake of patients. However, this was the first study that investigated the association between dietary intake and the risk of postcholecystectomic syndromes.

In conclusion, the present study found that postcholecystectomic syndromes were positively associated with the intake of cholesterol, animal protein, and eggs, and negatively associated with the intake of vegetables, suggesting that diet was plays a role in postcholecystectomic syndromes. However, clinical trials are needed to confirm the cause-effect relationship between dietary intake and postcholecystectomic syndromes.

\section{KEY MESSAGE}

1. Intake of cholesterol, animal protein, and eggs was positively, but intake of vegetables was negatively associated with postcholecystectomic syndromes.

2. Symptomatic patients consumed more breadbased breakfast foods, while asymptomatic patients consumed more rice.

\section{Conflict of interest}

No potential conflict of interest relevant to this article was reported.

\section{Acknowledgments}

The authors are grateful to the patients and their caregivers for their involvement in this study. This research was supported by Basic Science Research Program through the National Research Foundation of Korea (NRF) funded by the Ministry of Education (NRF2015R1DiA1A09060823).

\section{REFERENCES}

1. Schirmer BD, Edge SB, Dix J, Hyser MJ, Hanks JB, Jones RS. Laparoscopic cholecystectomy: treatment of choice for symptomatic cholelithiasis. Ann Surg 1991;213:665-676.

2. Jaunoo SS, Mohandas S, Almond LM. Postcholecystectomy syndrome (PCS). Int J Surg 2010;8:15-17.

3. Malagelada JR, Go VL, Summerskill WH, Gamble WS. Bile acid secretion and biliary bile acid composition altered by cholecystectomy. Am J Dig Dis 1973;18:455-459.

4. Fort JM, Azpiroz F, Casellas F, Andreu J, Malagelada JR. Bowel habit after cholecystectomy: physiological changes and clinical implications. Gastroenterology 1996;111:617-622.

5. Sciarretta G, Furno A, Mazzoni M, Malaguti P. Post-cholecystectomy diarrhea: evidence of bile acid malabsorption assessed by SeHCAT test. Am J Gastroenterol 1992;87:1852-1854.

6. Svensson JO, Gelin J, Svanvik J. Gallstones, cholecystectomy, and duodenogastric reflux of bile acid. Scand J Gastroenterol 1986;21:181-187.

7. Wilson P, Jamieson JR, Hinder RA, et al. Pathologic duodenogastric reflux associated with persistence of symptoms after cholecystectomy. Surgery 1995;117:421-428.

8. Meshkinpour H, Mollot M. Sphincter of Oddi dysfunction and unexplained abdominal pain: clinical and manometric study. Dig Dis Sci 1992;37:257-261.

9. Evans PR, Dowsett JF, Bak Y'T, Chan YK, Kellow JE. Abnormal sphincter of Oddi response to cholecystokinin in postcholecystectomy syndrome patients with irritable bowel syndrome: the irritable sphincter. Dig Dis Sci 1995;40:1149-1156.

10. Yueh TP, Chen FY, Lin TE, Chuang MT. Diarrhea after laparoscopic cholecystectomy: associated factors and predictors. Asian J Surg 2014;37:171-177.

11. Cummings JH, Wiggins HS, Jenkins DJ, et al. Influence of diets high and low in animal fat on bowel habit, gastrointestinal transit time, fecal microflora, bile acid, and fat excretion. J Clin Invest 1978;61:953-963.

12. Arlow FL, Dekovich AA, Priest RJ, Beher WT. Bile acid-mediated postcholecystectomy diarrhea. Arch Intern Med 1987;147:1327-1329.

13. Fisher M, Spilias DC, Tong LK. Diarrhoea after laparoscopic cholecystectomy: incidence and main determinants. ANZ J Surg 2008;78:482-486.

14. Johnson AG. Gallstones and flatulent dyspepsia: cause or coincidence? Postgrad Med J 1971;47:767-772. 
15. Carvalho RV, Lorena SL, Almeida JR, Mesquita MA. Food intolerance, diet composition, and eating patterns in functional dyspepsia patients. Dig Dis Sci 2010;55:60-65.

16. Stanghellini V, Tosetti C, Paternico A, et al. Risk indicators of delayed gastric emptying of solids in patients with functional dyspepsia. Gastroenterology 1996;110:1036-1042.

17. Ministry of Health and Welfare. Korea National Health and Nutrition Examination Survey [Internet]. Sejong (KR): Ministry of Health and Welfare; c2011 [cited 2017 Sep 11]. Available from: http://knhanes.cdc.go.kr/.

18. Smith MJ, Cherian P, Raju GS, Dawson BF, Mahon S, Bardhan KD. Bile acid malabsorption in persistent diarrhoea. J R Coll Physicians Lond 2000;34:448-451.

19. Reddy BS, Mangat S, Sheinfil A, Weisburger JH, Wynder EL. Effect of type and amount of dietary fat and 1,2-dimethylhydrazine on biliary bile acids, fecal bile acids, and neutral sterols in rats. Cancer Res 1977;37:2132-2137.

20. Watson RG, Love AH. Gastric emptying in patients with flatulent dyspepsia, with and without gallbladder disease. Scand J Gastroenterol 1987;22:47-53.

21. Pelletier X, Thouvenot P, Belbraouet S, et al. Effect of egg consumption in healthy volunteers: influence of yolk, white or whole-egg on gastric emptying and on glycemic and hormonal responses. Ann Nutr Metab 1996;40:109-115.

22. Burn-Murdoch RA, Fisher MA, Hunt JN. The slowing of gastric emptying by proteins in test meals. J Physiol 1978;274:477-485.

23. Uchida K, Nomura Y, Kadowaki M, Takeuchi N, Yamamura Y. Effect of dietary cholesterol on cholesterol and bile acid metabolism in rats. Jpn J Pharmacol 1977;27:193-204.

24. Hutcheon DF, Bayless TM, Gadacz TR. Postcholecystectomy diarrhea. JAMA 1979;241:823-824.

25. Chang FY, Chen PH, Wu TC, et al. Prevalence of functional gastrointestinal disorders in Taiwan: questionnaire-based survey for adults based on the Rome III criteria. Asia Pac J Clin Nutr 2012;21:594-600.

26. Kern F Jr, Birkner HJ, Ostrower VS. Binding of bile acids by dietary fiber. Am J Clin Nutr 1978;31:S175-S179.

27. Adiotomre J, Eastwood MA, Edwards CA, Brydon WG. Dietary fiber: in vitro methods that anticipate nutrition and metabolic activity in humans. Am J Clin Nutr 1990;52:128134 .

28. Marciani L, Pritchard SE, Hellier-Woods C, et al. Delayed gastric emptying and reduced postprandial small bowel water content of equicaloric whole meal bread versus rice meals in healthy subjects: novel MRI insights. Eur J Clin Nutr 2013;67:754-758.

29. Benini L, Sembenini C, Salandini L, Dall'O E, Bonfante F, Vantini I. Gastric emptying of realistic meals with and without gluten in patients with coeliac disease: effect of jejunal mucosal recovery. Scand J Gastroenterol 2001;36:1044-1048.

30. Biesiekierski JR, Newnham ED, Irving PM, et al. Gluten causes gastrointestinal symptoms in subjects without celiac disease: a double-blind randomized placebo-controlled trial. Am J Gastroenterol 2011;106:508-514.

31. Ruhl CE, Everhart JE. Relationship of non-alcoholic fatty liver disease with cholecystectomy in the US population. Am J Gastroenterol 2013;108:952-958.

32. Nervi F, Arrese M. Cholecystectomy and NAFLD: does gallbladder removal have metabolic consequences? Am J Gastroenterol 2013;108:959-961.

33. Amigo L, Husche C, Zanlungo S, et al. Cholecystectomy increases hepatic triglyceride content and very-low-density lipoproteins production in mice. Liver Int 2011;31:52-64.

34. Post SM, Groenendijk M, Solaas K, Rensen PC, Princen HM. Cholesterol 7alpha-hydroxylase deficiency in mice on an $\mathrm{APOE}^{\star}$ 3-Leiden background impairs very-low-density lipoprotein production. Arterioscler Thromb Vasc Biol 2004;24:768-774.

35. Koo SH. Nonalcoholic fatty liver disease: molecular mechanisms for the hepatic steatosis. Clin Mol Hepatol 2013;19:210-215.

36. Zweers SJ, Booij KA, Komuta M, et al. The human gallbladder secretes fibroblast growth factor 19 into bile: towards defining the role of fibroblast growth factor 19 in the enterobiliary tract. Hepatology 2012;55:575-583.

37. Bhatnagar S, Damron HA, Hillgartner FB. Fibroblast growth factor-19, a novel factor that inhibits hepatic fatty acid synthesis. J Biol Chem 2009;284:10023-10033.

38. Feng B, Song Q. Does the common bile duct dilate after cholecystectomy? Sonographic evaluation in 234 patients. AJR Am J Roentgenol 1995;165:859-861.

39. Edmunds R, Katz S, Garciano V, Finby N. The common duct after cholecystectomy: interval report. Arch Surg 1971;103:79-81.

40. Le Quesne LP, Whiteside CG, Hand BH. The common bile duct after cholecystectomy. Br Med J 1959;1:329-332. 


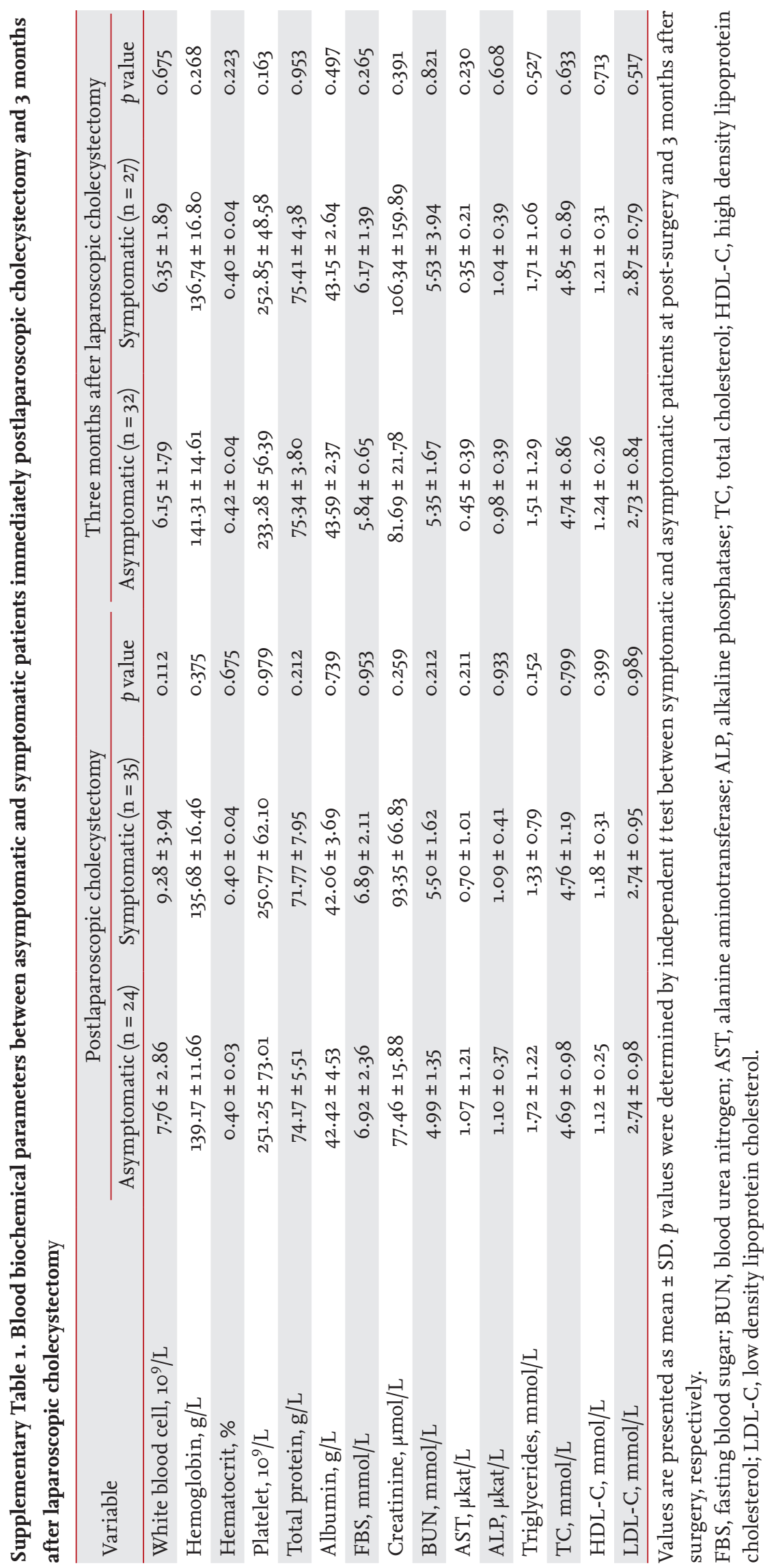


Supplementary Table 2. Daily intake of nutrients between asymptomatic and symptomatic patients at postlaparoscopic cholecystectomy

\begin{tabular}{|c|c|c|c|}
\hline Variable & Asymptomatic $(\mathrm{n}=24)$ & Symptomatic $(\mathrm{n}=35)$ & $p$ value \\
\hline Energy, kcal & $2,045.22 \pm 798.91$ & $2,230.51 \pm 715.96$ & 0.356 \\
\hline Carbohydrate, g/1,00o kcal & $149 \cdot 77 \pm 21.75$ & $153.73 \pm 24.12$ & 0.522 \\
\hline Lipid, g/1,0oo kcal & $26.19 \pm 7.04$ & $25.80 \pm 7.99$ & 0.848 \\
\hline Protein, g/1,ooo kcal & $39.32 \pm 6.58$ & $39.10 \pm 7.43$ & 0.909 \\
\hline Fiber, g/1,00o kcal & $10.63 \pm 2.69$ & $11.84 \pm 3.19$ & 0.133 \\
\hline Vitamin A, $\mu \mathrm{g}$ RE/1, ooo kcal & $365.38 \pm 212.55$ & $457.45 \pm 282.63$ & 0.181 \\
\hline Vitamin D, $\mu \mathrm{g} / 1,000 \mathrm{kcal}$ & $1.68 \pm 1.01$ & $1.63 \pm 0.65$ & 0.819 \\
\hline Vitamin E, mg/1,ooo kcal & $7.22 \pm 1.68$ & $8.03 \pm 2.03$ & 0.115 \\
\hline Vitamin $\mathrm{K}, \mu \mathrm{g} / 1,000 \mathrm{kcal}$ & $74.78 \pm 32.96$ & $94.94 \pm 48.37$ & 0.081 \\
\hline Thiamin, mg/1,ooo kcal & $0.66 \pm 0.10$ & $0.67 \pm 0.12$ & 0.588 \\
\hline Vitamin $\mathrm{B}_{6}, \mathrm{mg} / 1,000 \mathrm{kcal}$ & $0.81 \pm 0.15$ & $0.86 \pm 0.18$ & 0.287 \\
\hline Folate, $\mu \mathrm{g} / 1,000 \mathrm{kcal}$ & $254.56 \pm 74.74$ & $279.94 \pm 90.20$ & 0.261 \\
\hline Vitamin $\mathrm{B}_{12}, \mu \mathrm{g} / 1,000 \mathrm{kcal}$ & $4.37 \pm 1.38$ & $4.55 \pm 1.71$ & 0.674 \\
\hline Vitamin C, mg/1,ooo kcal & $55 \cdot 44 \pm 32.14$ & $60.33 \pm 31.79$ & 0.566 \\
\hline Calcium, mg/1,ooo kcal & $270.06 \pm 87.51$ & $271.24 \pm 81.75$ & 0.958 \\
\hline Phosphorus, mg/1,00o kcal & $581.81 \pm 84.08$ & $587.93 \pm 103.66$ & 0.811 \\
\hline Sodium, mg/1,ooo kcal & $1,945 \cdot 34 \pm 526.00$ & $2,142.26 \pm 559.64$ & 0.179 \\
\hline Potassium, mg/1, ooo kcal & $1,379.41 \pm 379.87$ & $1,492.63 \pm 432.08$ & 0.304 \\
\hline Magnesium, mg/1,0oo kcal & $39.48 \pm 9.80$ & $42.60 \pm 14.07$ & 0.351 \\
\hline Iron, mg/1, ০০o kcal & $7.48 \pm 1.22$ & $8.11 \pm 1.61$ & 0.110 \\
\hline Zinc, mg/1,ooo kcal & $5.74 \pm 0.94$ & $5.70 \pm 1.06$ & 0.861 \\
\hline Copper, mg/1,ooo kcal & $0.62 \pm 0.10$ & $0.65 \pm 0.13$ & 0.382 \\
\hline Selenium, $\mu \mathrm{g} / 1$, ooo kcal & $50.84 \pm 7.00$ & $49 \cdot 37 \pm 8.65$ & 0.491 \\
\hline Cholesterol, mg/1,00o kcal & $178.57 \pm 58.41$ & $187.30 \pm 61.68$ & 0.588 \\
\hline
\end{tabular}

Values are presented as mean $\pm \mathrm{SD}$. $p$ values were determined by independent $t$ test. RE, retinol equivalent. 
Shin Y, et al. Cholecystectomic symptoms and diet

Supplementary Table 3. Intake of foods between asymptomatic and symptomatic patients at postlaparoscopic cholecystectomy

\begin{tabular}{lccc}
\hline Variable & Asymptomatic $(\mathrm{n}=24)$ & Symptomatic $(\mathrm{n}=35)$ & $p$ value \\
\hline Grain, g & $311.38 \pm 123.01$ & $363.54 \pm 196.57$ & 0.216 \\
Potato, g & $38.88 \pm 35.32$ & $47.99 \pm 45.39$ & 0.412 \\
Legume, g & $94.10 \pm 84.33$ & $95.88 \pm 99.05$ & 0.943 \\
Vegetable, g & $228.28 \pm 170.84$ & $306.54 \pm 233.70$ & 0.166 \\
Fruit, g & $247.64 \pm 253.29$ & $260.85 \pm 186.93$ & 0.819 \\
Meat, g & $120.01 \pm 136.81$ & $100.71 \pm 106.67$ & 0.546 \\
Egg, g & $25.05 \pm 23.78$ & $29.09 \pm 22.00$ & 0.504 \\
Fish and seafood, g & $73.77 \pm 62.13$ & $67.28 \pm 64.61$ & 0.702 \\
Dairy product, g & $142.00 \pm 136.99$ & $145.97 \pm 123.87$ & 0.908 \\
Beverage, g & $335.87 \pm 269.61$ & $285.45 \pm 278.54$ & 0.492 \\
Others, g & $49.75 \pm 44.40$ & $46.82 \pm 65.68$ & 0.492 \\
\hline Values are & & &
\end{tabular}

Values are presented as mean \pm SD. $p$ values were determined by independent $t$ test. 
Supplementary Table 4. Daily intake of nutrients and foods between asymptomatic and symptomatic patients at 3 months after laparoscopic cholecystectomy

\begin{tabular}{|c|c|c|c|}
\hline Variable & Asymptomatic $(\mathrm{n}=32)$ & Symptomatic $(\mathrm{n}=27)$ & $p$ value \\
\hline Vitamin A, $\mu \mathrm{g}$ RE/1, ooo kcal & $541.79 \pm 590.00$ & $479.65 \pm 323.31$ & 0.627 \\
\hline Vitamin D, $\mu \mathrm{g} / 1$, ooo kcal & $2.67 \pm 8.92$ & $2.28 \pm 3.07$ & 0.828 \\
\hline Vitamin E, mg/1,ooo kcal & $8.89 \pm 5.25$ & $8.45 \pm 4.62$ & 0.734 \\
\hline Vitamin $\mathrm{K}, \mu \mathrm{g} / 1,000 \mathrm{kcal}$ & $121.55 \pm 107.13$ & $124.71 \pm 119.64$ & 0.915 \\
\hline Thiamin, mg/1,ooo kcal & $0.69 \pm 0.32$ & $0.65 \pm 0.20$ & 0.540 \\
\hline Vitamin $\mathrm{B}_{6}, \mathrm{mg} / \mathrm{1}, 00 \mathrm{occal}$ & $0.85 \pm 0.34$ & $0.79 \pm 0.39$ & 0.527 \\
\hline Folate, $\mu \mathrm{g} / 1,000 \mathrm{kcal}$ & $268.11 \pm 119.80$ & $242.39 \pm 121.03$ & 0.417 \\
\hline Vitamin $\mathrm{B}_{12}, \mu \mathrm{g} / 1,000 \mathrm{kcal}$ & $5.88 \pm 5.58$ & $5 \cdot 90 \pm 4.30$ & 0.993 \\
\hline Vitamin C, mg/1,ooo kcal & $66.85 \pm 33.81$ & $57.85 \pm 48.90$ & 0.409 \\
\hline Calcium, mg/1,ooo kcal & $273.00 \pm 110.07$ & $253.72 \pm 118.82$ & 0.521 \\
\hline Phosphorus, mg/1,0oo kcal & $541.06 \pm 145.25$ & $567.06 \pm 192.75$ & 0.557 \\
\hline Sodium, mg/1,ooo kcal & $2,535.20 \pm 897.13$ & $2,449.44 \pm 909.92$ & 0.718 \\
\hline Potassium, mg/1,ooo kcal & $1,577.74 \pm 528.12$ & $1,636.90 \pm 692.54$ & 0.711 \\
\hline Magnesium, mg/1,ooo kcal & $43.85 \pm 30.73$ & $49.39 \pm 32.80$ & 0.507 \\
\hline Iron, mg/1,ooo kcal & $8.87 \pm 4.40$ & $9.16 \pm 4.47$ & 0.800 \\
\hline Zinc, mg/1,ooo kcal & $5.45 \pm 2.01$ & $5.26 \pm 1.90$ & 0.715 \\
\hline Copper, mg/1,0oo kcal & $0.71 \pm 0.39$ & $0.68 \pm 0.37$ & 0.771 \\
\hline Selenium, $\mu \mathrm{g} / 1$, ooo kcal & $39.81 \pm 17.59$ & $40.96 \pm 29.63$ & 0.853 \\
\hline Sweets, g & $17.23 \pm 43 \cdot 37$ & $16.85 \pm 42.00$ & 0.973 \\
\hline Legumes, $g$ & $33.01 \pm 55.21$ & $28.90 \pm 47.43$ & 0.763 \\
\hline Seaweeds, g & $2.98 \pm 4.73$ & $2.72 \pm 3.97$ & 0.827 \\
\hline Oils and seeds, g & $13.48 \pm 10.36$ & $9.52 \pm 10.98$ & 0.160 \\
\hline Beverage, g & $203.93 \pm 284.96$ & $276.59 \pm 319.67$ & 0.360 \\
\hline Seasonings, $\mathrm{g}$ & $35.47 \pm 28.67$ & $25.64 \pm 17.38$ & 0.126 \\
\hline
\end{tabular}

Values are presented as mean \pm SD. $p$ values were determined by independent $t$ test.

$\mathrm{RE}$, retinol equivalent. 
Shin Y, et al. Cholecystectomic symptoms and diet

Supplementary Table 5 . Association between nutrients intake and the risk of symptom at postlaparoscopic cholecystectomy by multivariable logistic regression analysis

\begin{tabular}{|c|c|c|c|c|}
\hline \multirow{2}{*}{ Variable } & \multicolumn{3}{|c|}{ Quartile of dietary intake } & \multirow{2}{*}{$p$ for trend ${ }^{a}$} \\
\hline & Q1 & Q2 & Q3 & \\
\hline \multicolumn{5}{|l|}{ Carbohydrate, g } \\
\hline Number of S/A & $6 / 8$ & $8 / 8$ & $21 / 8$ & \\
\hline Cut-off & $\leq 237.1$ & $237.1<$ to $\leq 319.6$ & $>319.6$ & 0.185 \\
\hline OR $(95 \% \mathrm{CI})^{\mathrm{b}}$ & 1 & $1.203(0.25-5.86)$ & $3.825(0.54-27.29)$ & \\
\hline \multicolumn{5}{|l|}{ Lipid, g } \\
\hline Number of S/A & $5 / 8$ & $16 / 8$ & $14 / 8$ & \\
\hline Cut-off & $\leq 34.9$ & $34.9<$ to $\leq 59 \cdot 5$ & $>59 \cdot 5$ & 0.399 \\
\hline OR $(95 \% \mathrm{CI})$ & 1 & $3.102(0.57-16.95)$ & $3.121(0.34-28.76)$ & \\
\hline \multicolumn{5}{|l|}{ Protein, g } \\
\hline Number of S/A & $3 / 8$ & $18 / 8$ & $14 / 8$ & \\
\hline Cut-off & $\leq 53.7$ & $53.7<$ to $\leq 90.5$ & $>90.5$ & 0.462 \\
\hline OR $(95 \% \mathrm{CI})$ & 1 & $4.667(0.75-29.02)$ & $3.897(0.31-49.00)$ & \\
\hline \multicolumn{5}{|l|}{ Fiber, g } \\
\hline Number of S/A & $6 / 9$ & $8 / 8$ & $21 / 7$ & \\
\hline Cut-off & $\leq 16.3$ & $16.3<$ to $\leq 23.9$ & $>23.9$ & 0.072 \\
\hline OR (95\% CI) & 1 & $1.865(0.37-9.39)$ & $5.123(0.81-32.53)$ & \\
\hline \multicolumn{5}{|l|}{ Vitamin A, $\mu \mathrm{g}$ RE } \\
\hline Number of S/A & $6 / 8$ & $13 / 8$ & $16 / 8$ & \\
\hline Cut-off & $\leq 489.7$ & $489.7<$ to $\leq 792.6$ & $>792.6$ & 0.388 \\
\hline OR $(95 \% \mathrm{CI})$ & 1 & $1.881(0.38-9.35)$ & $2.542(0.38-16.84)$ & \\
\hline \multicolumn{5}{|l|}{ Vitamin $\mathrm{D}, \mu \mathrm{g}$} \\
\hline Number of S/A & $10 / 8$ & $11 / 8$ & $14 / 8$ & \\
\hline Cut-off & $\leq 2.0$ & $2.0<$ to $\leq 3.7$ & $>3.7$ & 0.762 \\
\hline OR $(95 \% \mathrm{CI})$ & 1 & $0.820(0.18-3.69)$ & $1.167(0.20-6.78)$ & \\
\hline \multicolumn{5}{|l|}{ Vitamin E, mg } \\
\hline Number of S/A & $5 / 8$ & $15 / 8$ & $15 / 8$ & \\
\hline Cut-off & $\leq 11.4$ & $11.4<$ to $\leq 16.2$ & $>16.2$ & 0.823 \\
\hline OR $(95 \% \mathrm{CI})$ & 1 & $2.419(0.44-13.35)$ & $1.922(0.22-16.78)$ & \\
\hline \multicolumn{5}{|l|}{ Vitamin $\mathrm{K}, \mu \mathrm{g}$} \\
\hline Number of S/A & $5 / 8$ & $11 / 8$ & $19 / 8$ & \\
\hline Cut-off & $\leq 96.6$ & $96.6<$ to $\leq 163.0$ & $>163.0$ & 0.348 \\
\hline OR $(95 \% \mathrm{CI})$ & 1 & $1.319(0.27-6.54)$ & $2.263(0.37-13.80)$ & \\
\hline \multicolumn{5}{|l|}{ Thiamin, mg } \\
\hline Number of S/A & $4 / 8$ & $13 / 8$ & $18 / 8$ & \\
\hline Cut-off & $\leq 0.9$ & $0.9<$ to $\leq 1.4$ & $>1.4$ & 0.177 \\
\hline OR (95\% CI) & 1 & $2.741(0.47-15.83)$ & $5.463(0.54-54.82)$ & \\
\hline \multicolumn{5}{|l|}{ Vitamin $\mathrm{B}_{6}, \mathrm{mg}$} \\
\hline Number of S/A & $4 / 8$ & $19 / 8$ & $12 / 8$ & \\
\hline Cut-off & $\leq 1.2$ & $1.2<$ to $\leq 2.0$ & $>2.0$ & 0.778 \\
\hline OR $(95 \% \mathrm{CI})$ & 1 & $3.791(0.62-23.08)$ & $2.093(0.20-22.33)$ & \\
\hline \multicolumn{5}{|l|}{ Folate, $\mu \mathrm{g}$} \\
\hline Number of S/A & $6 / 8$ & $8 / 8$ & $21 / 8$ & \\
\hline
\end{tabular}


Supplementary Table 5. Continued

\begin{tabular}{|c|c|c|c|c|}
\hline \multirow{2}{*}{ Variable } & \multicolumn{3}{|c|}{ Quartile of dietary intake } & \multirow{2}{*}{$p$ for trend } \\
\hline & Q1 & Q2 & Q3 & \\
\hline Cut-off & $\leq 358.2$ & $358.2<$ to $\leq 550.8$ & $>550.8$ & 0.117 \\
\hline OR $(95 \% \mathrm{CI})$ & 1 & $1.559(0.28-8.69)$ & $4.357(0.57-33.37)$ & \\
\hline \multicolumn{5}{|l|}{ Vitamin $\mathrm{B}_{12}, \mu \mathrm{g}$} \\
\hline Number of S/A & $11 / 8$ & $8 / 8$ & $16 / 8$ & \\
\hline Cut-off & $\leq 7.2$ & $7.2<$ to $\leq 9.8$ & $>9.8$ & 0.958 \\
\hline OR $(95 \% \mathrm{CI})$ & 1 & $0.480(0.10-2.22)$ & $0.861(0.17-4.29)$ & \\
\hline \multicolumn{5}{|l|}{ Vitamin C, mg } \\
\hline Number of S/A & $3 / 8$ & $12 / 8$ & $20 / 8$ & \\
\hline Cut-off & $\leq 59 \cdot 5$ & $59.5<$ to $\leq 106.7$ & $>106.7$ & 0.085 \\
\hline OR $(95 \% \mathrm{CI})$ & 1 & $3.103\left(0.55^{-17.59)}\right.$ & $5.914(0.96-36.52)$ & \\
\hline \multicolumn{5}{|l|}{ Calcium, mg } \\
\hline Number of S/A & $8 / 8$ & $10 / 8$ & $17 / 8$ & \\
\hline Cut-off & $\leq 384.3$ & $384.3<$ to $\leq 612.8$ & $>612.8$ & 0.239 \\
\hline OR $(95 \% \mathrm{CI})$ & 1 & $1.319(0.27-6.36)$ & $2.834(0.43-18.55)$ & \\
\hline \multicolumn{5}{|l|}{ Phosphorus, mg } \\
\hline Number of S/A & $5 / 8$ & $19 / 8$ & $11 / 8$ & \\
\hline Cut-off & $\leq 802.8$ & $802.8<$ to $\leq 1,425.1$ & $>1,425.1$ & 0.966 \\
\hline OR $(95 \% \mathrm{CI})$ & 1 & $2.947(0.52-16.69)$ & $1.278(0.11-14.76)$ & \\
\hline \multicolumn{5}{|l|}{ Sodium, mg } \\
\hline Number of S/A & $6 / 8$ & $12 / 8$ & $17 / 8$ & \\
\hline Cut-off & $\leq 2,901.2$ & $2,901.2<$ to $\leq 4,395.9$ & $>4,395 \cdot 9$ & 0.362 \\
\hline OR $(95 \% \mathrm{CI})$ & 1 & $1.927(0.38-9.72)$ & $2.819(0.35-22.79)$ & \\
\hline \multicolumn{5}{|l|}{ Potassium, mg } \\
\hline Number of S/A & $5 / 8$ & $9 / 8$ & $21 / 8$ & \\
\hline Cut-off & $\leq 2,055 \cdot 7$ & $2,055.7<$ to $\leq 2,976.0$ & $>2,976.0$ & 0.055 \\
\hline OR $(95 \% \mathrm{CI})$ & 1 & $2.269(0.42-12.27)$ & $7.322(0.93-57.92)$ & \\
\hline \multicolumn{5}{|l|}{ Magnesium, mg } \\
\hline Number of S/A & $6 / 8$ & $15 / 8$ & $14 / 8$ & \\
\hline Cut-off & $\leq 56.0$ & $56.0<$ to $\leq 102.8$ & $>102.8$ & 0.925 \\
\hline OR $(95 \% \mathrm{CI})$ & 1 & $2.120(0.40-11.23)$ & $1.646(0.22-12.26)$ & \\
\hline \multicolumn{5}{|l|}{ Iron, mg } \\
\hline Number of S/A & $5 / 8$ & $12 / 8$ & $18 / 8$ & \\
\hline Cut-off & $\leq 11.7$ & $11.7<$ to $\leq 16.7$ & $>16.7$ & 0.157 \\
\hline OR $(95 \% \mathrm{CI})$ & 1 & $2.933(0.53-16.34)$ & $5.667(0.60-53.1)$ & \\
\hline \multicolumn{5}{|l|}{ Zinc, mg } \\
\hline Number of S/A & $6 / 8$ & $14 / 8$ & $15 / 8$ & \\
\hline Cut-off & $\leq 8.2$ & $8.2<$ to $\leq 12.6$ & $>12.6$ & 0.620 \\
\hline OR $(95 \% \mathrm{CI})$ & 1 & $2.033(0.37-11.10)$ & $2.218(0.23-20.98)$ & \\
\hline \multicolumn{5}{|l|}{ Copper, mg } \\
\hline Number of S/A & $7 / 8$ & $12 / 8$ & $16 / 8$ & \\
\hline Cut-off & $\leq 1.0$ & $1.0<$ to $\leq 1.4$ & $>1.4$ & 0.535 \\
\hline OR $(95 \% \mathrm{CI})$ & 1 & $1.723(0.33-9.04)$ & $2.045(0.28-15.05)$ & \\
\hline Selenium, $\mu \mathrm{g}$ & & & & \\
\hline
\end{tabular}


Shin Y, et al. Cholecystectomic symptoms and diet

Supplementary Table 5. Continued

\begin{tabular}{|c|c|c|c|c|}
\hline \multirow{2}{*}{ Variable } & \multicolumn{3}{|c|}{ Quartile of dietary intake } & \multirow{2}{*}{$p$ for trend $d^{a}$} \\
\hline & Q1 & $\mathrm{Q}_{2}$ & Q3 & \\
\hline Number of S/A & $9 / 8$ & $15 / 8$ & $11 / 8$ & \\
\hline Cut-off & $\leq 78.3$ & $78.3<$ to $\leq 118.8$ & $>118.8$ & 0.399 \\
\hline OR (95\% CI) & 1 & $0.947(0.17-5.16)$ & $0.370(0.03-5.09)$ & \\
\hline \multicolumn{5}{|l|}{ Cholesterol, mg } \\
\hline Number of S/A & $9 / 8$ & $11 / 8$ & $15 / 8$ & \\
\hline Cut-off & $\leq 269.2$ & $269.2<$ to $\leq 414.5$ & $>414.5$ & 0.781 \\
\hline OR $(95 \% \mathrm{CI})$ & 1 & $1.216(0.28-5.30)$ & $1.331(0.21-8.22)$ & \\
\hline
\end{tabular}

S/A, symptomatic/asymptomatic; OR, odds ratio; CI, confidence interval; RE, retinol equivalent.

${ }^{a}$ Estimates of $p$ values for a linear trend were based on linear scores derived from the medians of quartiles for intake of nutrients among asymptomatic patients.

${ }^{\mathrm{b}}$ OR was adjusted for total energy intake and medical of digestive system disease. 
Supplementary Table 6. Association between food intake and the risk of symptom at postlaparoscopic cholecystectomy by multivariable logistic regression analysis

\begin{tabular}{|c|c|c|c|c|}
\hline \multirow{2}{*}{ Variable } & \multicolumn{3}{|c|}{ Quartile of dietary intake } & \multirow{2}{*}{$p$ for trend ${ }^{a}$} \\
\hline & Q1 & $\mathrm{Q}_{2}$ & Q3 & \\
\hline \multicolumn{5}{|l|}{ Grain, g } \\
\hline Number of S/A & $13 / 8$ & $3 / 8$ & $19 / 8$ & \\
\hline Cut-off & $\leq 253.7$ & $253.7<$ to $\leq 346.5$ & $>346.5$ & 0.873 \\
\hline OR $(95 \% \mathrm{CI})^{\mathrm{b}}$ & 1 & $0.185(0.03-1.05)$ & $1.050(0.23-4.76)$ & \\
\hline \multicolumn{5}{|l|}{ Potato, g } \\
\hline Number of S/A & $7 / 8$ & $17 / 8$ & $11 / 8$ & \\
\hline Cut-off & $\leq 13.2$ & $13.2<$ to $\leq 47.1$ & $>47.1$ & 0.649 \\
\hline OR (95\% CI) & 1 & $3.008(0.71-12.75)$ & $1.312(0.29-5.94)$ & \\
\hline \multicolumn{5}{|l|}{ Legume, g } \\
\hline Number of S/A & $12 / 8$ & $14 / 8$ & $9 / 8$ & \\
\hline Cut-off & $\leq 38.4$ & $38.4<$ to $\leq 122.8$ & $>122.8$ & 0.461 \\
\hline OR $(95 \% \mathrm{CI})$ & 1 & $0.732(0.18-2.91)$ & $0.550(0.13-2.40)$ & \\
\hline \multicolumn{5}{|l|}{ Vegetable, g } \\
\hline Number of S/A & $6 / 8$ & $11 / 8$ & $18 / 8$ & \\
\hline Cut-off & $\leq 126.3$ & $126.3<$ to $\leq 222.3$ & $>222.3$ & 0.434 \\
\hline OR $(95 \% \mathrm{CI})$ & 1 & $2.034(0.45-9.16)$ & $2.223(0.46-10.83)$ & \\
\hline \multicolumn{5}{|l|}{ Fruit, g } \\
\hline Number of S/A & $8 / 8$ & $7 / 8$ & $20 / 8$ & \\
\hline Cut-off & $\leq 120.4$ & $120.4<$ to $\leq 187.2$ & $>187.2$ & 0.229 \\
\hline OR $(95 \% \mathrm{CI})$ & 1 & $0.667(0.14-3.09)$ & $1.690(0.43-6.70)$ & \\
\hline \multicolumn{5}{|l|}{ Meat, g } \\
\hline Number of S/A & $17 / 8$ & $8 / 8$ & $10 / 8$ & \\
\hline Cut-off & $\leq 50.7$ & $50.7<$ to $\leq 129.3$ & $>129.3$ & 0.274 \\
\hline OR $(95 \% \mathrm{CI})$ & 1 & $0.369(0.09-1.54)$ & $0.361(0.08-1.69)$ & \\
\hline \multicolumn{5}{|l|}{ Egg, g } \\
\hline Number of S/A & $8 / 9$ & $11 / 7$ & $16 / 8$ & \\
\hline Cut-off & $\leq 15.2$ & $15.2<$ to $\leq 31.2$ & $>31.2$ & 0.382 \\
\hline OR $(95 \% \mathrm{CI})$ & 1 & $1.159(0.24-5.49)$ & $1.788(0.43-7.36)$ & \\
\hline \multicolumn{5}{|c|}{ Fish and seafood, g } \\
\hline Number of S/A & $14 / 8$ & $13 / 8$ & $8 / 8$ & \\
\hline Cut-off & $\leq 40.6$ & $40.6<$ to $\leq 88.6$ & $>88.6$ & 0.355 \\
\hline OR (95\% CI) & 1 & $1.205(0.32-4.60)$ & $0.503(0.10-2.42)$ & \\
\hline \multicolumn{5}{|l|}{ Dairy product, g } \\
\hline Number of S/A & $12 / 8$ & $10 / 8$ & $13 / 8$ & \\
\hline Cut-off & $\leq 56.9$ & $56.9<$ to $\leq 174.6$ & $>174.6$ & 0.609 \\
\hline OR $(95 \% \mathrm{CI})$ & 1 & $0.413(0.09-1.98)$ & $1.195(0.29-4.94)$ & \\
\hline \multicolumn{5}{|l|}{ Beverage, g } \\
\hline Number of S/A & $16 / 8$ & $11 / 8$ & $8 / 8$ & \\
\hline Cut-off & $\leq 177.1$ & $177.1<$ to $\leq 423.6$ & $>423.6$ & 0.311 \\
\hline OR (95\% CI) & 1 & $0.822(0.20-3.31)$ & $0.428(0.09-2.15)$ & \\
\hline \multicolumn{5}{|l|}{ Others, $g$} \\
\hline Number of S/A & $17 / 8$ & $9 / 8$ & $9 / 8$ & \\
\hline Cut-off & $\leq 20.9$ & $20.9<$ to $\leq 57.1$ & $>57.1$ & 0.249 \\
\hline OR $(95 \% \mathrm{CI})$ & 1 & $0.417(0.10-1.71)$ & $0.332(0.07-1.48)$ & \\
\hline
\end{tabular}

S/A, symptomatic/asymptomatic; OR, odds ratio; CI, confidence interval.

${ }^{a}$ Estimates of $p$ values for a linear trend were based on linear scores derived from the medians of quartiles for intake of nutrients among asymptomatic patients.

${ }^{\mathrm{b}} \mathrm{OR}$ was adjusted for total energy intake and medical of digestive system disease. 
Shin Y, et al. Cholecystectomic symptoms and diet

Supplementary Table 7. Association between nutrients intake and the risk of symptom at 3 months after laparoscopic cholecystectomy by multivariable logistic regression analysis

\begin{tabular}{|c|c|c|c|c|}
\hline \multirow{2}{*}{ Variable } & \multicolumn{3}{|c|}{ Quartile of dietary intake } & \multirow{2}{*}{$p$ for trend ${ }^{a}$} \\
\hline & Q1 & Q2 & Q3 & \\
\hline \multicolumn{5}{|l|}{ Carbohydrate, g } \\
\hline Number of S/A & $13 / 10$ & $8 / 11$ & $6 / 11$ & \\
\hline Cut-off & $\leq 218.4$ & $218.4<$ to $\leq 282.2$ & $>282.2$ & 0.116 \\
\hline $\mathrm{OR}(95 \% \mathrm{CI})^{\mathrm{b}}$ & 1 & $0.479(0.11-2.07)$ & $0.244(0.04-1.42)$ & \\
\hline \multicolumn{5}{|l|}{ Lipid, g } \\
\hline Number of S/A & $12 / 10$ & $6 / 11$ & $9 / 11$ & \\
\hline Cut-off & $\leq 33.4$ & $33.4<$ to $\leq 45.4$ & $>45 \cdot 4$ & 0.612 \\
\hline OR $(95 \% \mathrm{CI})$ & 1 & $0.476(0.11-1.98)$ & $0.728(0.13-4.05)$ & \\
\hline \multicolumn{5}{|l|}{ Protein, g } \\
\hline Number of S/A & $8 / 11$ & $3 / 9$ & $16 / 12$ & \\
\hline Cut-off & $\leq 47.1$ & $47.1<$ to $\leq 66.5$ & $>66.5$ & 0.052 \\
\hline OR $(95 \% \mathrm{CI})$ & 1 & $0.727(0.12-4.29)$ & $4.576(0.90-23.17)$ & \\
\hline \multicolumn{5}{|l|}{ Plant protein, g } \\
\hline Number of S/A & $15 / 10$ & $5 / 11$ & $7 / 11$ & \\
\hline Cut-off & $\leq 29.4$ & $29.4<$ to $\leq 38.1$ & $>38.1$ & 0.456 \\
\hline OR $(95 \% \mathrm{CI})$ & 1 & $0.238(0.05-1.09)$ & $0.568(0.13-2.54)$ & \\
\hline \multicolumn{5}{|l|}{ Fiber, g } \\
\hline Number of S/A & $12 / 11$ & $11 / 10$ & $4 / 11$ & \\
\hline Cut-off & $\leq 16.7$ & $16.7<$ to $\leq 23.8$ & $>23.8$ & 0.137 \\
\hline OR $(95 \% \mathrm{CI})$ & 1 & $1.329(0.36-4.87)$ & $0.333(0.07-1.68)$ & \\
\hline \multicolumn{5}{|l|}{ Vitamin A, $\mu \mathrm{g}$ RE } \\
\hline Number of S/A & $9 / 10$ & $9 / 11$ & $9 / 11$ & \\
\hline Cut-off & $\leq 420.0$ & $420.0<$ to $\leq 891.9$ & $>891.9$ & 0.614 \\
\hline OR (95\% CI) & 1 & $0.642(0.16-2.52)$ & $0.652(0.16-2.70)$ & \\
\hline \multicolumn{5}{|l|}{ Vitamin $\mathrm{D}, \mu \mathrm{g}$} \\
\hline Number of S/A & $5 / 10$ & $7 / 11$ & $15 / 11$ & \\
\hline Cut-off & $\leq 0.2$ & $0.2<$ to $\leq 1.5$ & $>1.5$ & 0.062 \\
\hline OR $(95 \% \mathrm{CI})$ & 1 & $1.258(0.26-6.14)$ & $3.544(0.79-15.98)$ & \\
\hline \multicolumn{5}{|l|}{ Vitamin E, mg } \\
\hline Number of S/A & $11 / 10$ & $10 / 11$ & $6 / 11$ & \\
\hline Cut-off & $\leq 10.5$ & $10.5<$ to $\leq 17.2$ & $>17.2$ & 0.249 \\
\hline OR (95\% CI) & 1 & $0.799(0.22-2.91)$ & $0.380(0.08-1.78)$ & \\
\hline \multicolumn{5}{|l|}{ Vitamin $\mathrm{K}, \mu \mathrm{g}$} \\
\hline Number of S/A & $11 / 11$ & $7 / 10$ & $9 / 11$ & \\
\hline Cut-off & $\leq 94.3$ & $94.3<$ to $\leq 205.5$ & $>205 \cdot 5$ & 0.756 \\
\hline OR $(95 \% \mathrm{CI})$ & 1 & $0.603\left(0.15^{-2.43}\right)$ & $0.778(0.21-2.86)$ & \\
\hline \multicolumn{5}{|l|}{ Thiamin, mg } \\
\hline Number of S/A & $11 / 10$ & $8 / 11$ & $8 / 11$ & \\
\hline Cut-off & $\leq 0.9$ & $0.9<$ to $\leq 1.2$ & $>1.2$ & 0.600 \\
\hline OR $(95 \% \mathrm{CI})$ & 1 & $0.762(0.20-2.96)$ & $0.675(0.15-30.00)$ & \\
\hline \multicolumn{5}{|l|}{ Vitamin $\mathrm{B}_{6}, \mathrm{mg}$} \\
\hline Number of S/A & $14 / 11$ & $9 / 11$ & $4 / 10$ & \\
\hline
\end{tabular}


Supplementary Table 7. Continued

\begin{tabular}{|c|c|c|c|c|}
\hline \multirow{2}{*}{ Variable } & \multicolumn{3}{|c|}{ Quartile of dietary intake } & \multirow{2}{*}{$p$ for trend $d^{a}$} \\
\hline & Q1 & Q2 & Q3 & \\
\hline Cut-off & $\leq 1.1$ & $1.1<$ to $\leq 1.7$ & $>1.7$ & 0.203 \\
\hline OR $(95 \% \mathrm{CI})$ & 1 & $0.667(0.19-2.38)$ & $0.342(0.07-1.70)$ & \\
\hline \multicolumn{5}{|l|}{ Folate, $\mu \mathrm{g}$} \\
\hline Number of S/A & $12 / 10$ & $10 / 11$ & $5 / 11$ & \\
\hline Cut-off & $\leq 326.6$ & $326.6<$ to $\leq 526.2$ & $>526.2$ & 0.183 \\
\hline OR $(95 \% \mathrm{CI})$ & 1 & $0.803(0.22-2.92)$ & $0.357(0.08-1.64)$ & \\
\hline \multicolumn{5}{|l|}{ Vitamin $\mathrm{B}_{12}, \mu \mathrm{g}$} \\
\hline Number of S/A & $10 / 10$ & $9 / 11$ & $8 / 11$ & \\
\hline Cut-off & $\leq 5.2$ & $5.2<$ to $\leq 9.5$ & $>9.5$ & 0.887 \\
\hline OR $(95 \% \mathrm{CI})$ & 1 & $0.866(0.22-3.37)$ & $0.886(0.23-3.48)$ & \\
\hline \multicolumn{5}{|l|}{ Vitamin C, mg } \\
\hline Number of S/A & $17 / 10$ & $4 / 13$ & $6 / 9$ & \\
\hline Cut-off & $\leq 82.8$ & $82.8<$ to $\leq 133.9$ & $>133.9$ & 0.089 \\
\hline OR $(95 \% \mathrm{CI})$ & 1 & $0.238(0.06-1.01)$ & $0.355(0.09-1.47)$ & \\
\hline \multicolumn{5}{|l|}{ Calcium, mg } \\
\hline Number of S/A & $14 / 11$ & $5 / 9$ & $8 / 12$ & \\
\hline Cut-off & $\leq 372.4$ & $372.4<$ to $\leq 457.6$ & $>457.6$ & 0.374 \\
\hline OR $(95 \% \mathrm{CI})$ & 1 & $0.520(0.12-2.30)$ & $0.524(0.14-1.97)$ & \\
\hline \multicolumn{5}{|l|}{ Phosphorus, mg } \\
\hline Number of S/A & $10 / 10$ & $10 / 11$ & $7 / 11$ & \\
\hline Cut-off & $\leq 759 \cdot 3$ & $759 \cdot 3<$ to $\leq 1,041.6$ & $>1,041.6$ & 0.927 \\
\hline OR $(95 \% \mathrm{CI})$ & 1 & $1.655(0.40-6.61)$ & $0.995(0.19-5.23)$ & \\
\hline \multicolumn{5}{|l|}{ Sodium, mg } \\
\hline Number of S/A & $14 / 10$ & $5 / 11$ & $8 / 11$ & \\
\hline Cut-off & $\leq 3,370.6$ & $3,370.6<$ to $\leq 4,601.8$ & $>4,601.8$ & 0.758 \\
\hline $\mathrm{OR}(95 \% \mathrm{CI})$ & 1 & $0.260\left(0.05^{-1.25}\right)$ & $0.670(0.16-2.90)$ & \\
\hline \multicolumn{5}{|l|}{ Potassium, mg } \\
\hline Number of S/A & $7 / 10$ & $15 / 11$ & $5 / 11$ & \\
\hline Cut-off & $\leq 1,951.7$ & $1,951.7<$ to $\leq 2,966.7$ & $>2,966.7$ & 0.976 \\
\hline OR (95\% CI) & 1 & $3.940(0.85-18.21)$ & $1.359(0.25-7.52)$ & \\
\hline \multicolumn{5}{|l|}{ Magnesium, mg } \\
\hline Number of S/A & $7 / 10$ & $8 / 11$ & $12 / 11$ & \\
\hline Cut-off & $\leq 45 \cdot 3$ & $45 \cdot 3<$ to $\leq 81.6$ & $>81.6$ & 0.236 \\
\hline OR $(95 \% \mathrm{CI})$ & 1 & $1.536(0.34-6.88)$ & $2.425(0.56-10.57)$ & \\
\hline \multicolumn{5}{|l|}{ Iron, mg } \\
\hline Number of S/A & $10 / 10$ & $8 / 11$ & $9 / 11$ & \\
\hline Cut-off & $\leq 10.6$ & $10.6<$ to $\leq 15.3$ & $>15 \cdot 3$ & 0.987 \\
\hline OR $(95 \% \mathrm{CI})$ & 1 & $0.598(0.14-2.62)$ & $0.912(0.23-3.67)$ & \\
\hline \multicolumn{5}{|l|}{ Zinc, mg } \\
\hline Number of S/A & $11 / 10$ & $8 / 11$ & $8 / 11$ & \\
\hline Cut-off & $\leq 7.0$ & $7.0<$ to $\leq 10.4$ & $>10.4$ & 0.893 \\
\hline OR $(95 \% \mathrm{CI})$ & 1 & $0.845(0.22-3.27)$ & $0.906(0.21-3.94)$ & \\
\hline Copper, mg & & & & \\
\hline
\end{tabular}


Shin Y, et al. Cholecystectomic symptoms and diet

Supplementary Table 7. Continued

\begin{tabular}{|c|c|c|c|c|}
\hline \multirow{2}{*}{ Variable } & \multicolumn{3}{|c|}{ Quartile of dietary intake } & \multirow{2}{*}{$p$ for trend } \\
\hline & Q1 & Q2 & Q3 & \\
\hline Number of S/A & $13 / 10$ & $8 / 11$ & $6 / 11$ & \\
\hline Cut-off & $\leq 0.9$ & $0.9<$ to $\leq 1.3$ & $>1.3$ & 0.310 \\
\hline OR $(95 \% \mathrm{CI})$ & 1 & $0.664(0.18-2.50)$ & $0.466(0.11-1.92)$ & \\
\hline \multicolumn{5}{|l|}{ Selenium, $\mu \mathrm{g}$} \\
\hline Number of S/A & $14 / 10$ & $6 / 11$ & $7 / 11$ & \\
\hline Cut-off & $\leq 47.0$ & $47.0<$ to $\leq 78.2$ & $>78.2$ & 0.371 \\
\hline OR $(95 \% \mathrm{CI})$ & 1 & $0.417(0.11-1.66)$ & $0.511(0.13-2.05)$ & \\
\hline
\end{tabular}

S/A, symptomatic/asymptomatic; OR, odds ratio; CI, confidence interval; RE, retinol equivalent.

${ }^{a}$ Estimates of $p$ values for a linear trend were based on linear scores derived from the medians of quartiles for intake of nutrients among asymptomatic.

${ }^{\mathrm{b}}$ OR was adjusted for total energy, exercise frequency. 
Supplementary Table 8. Association between food intake and the risk of symptom at 3 months after laparoscopic cholecystectomy by multivariable logistic regression analysis

\begin{tabular}{|c|c|c|c|c|}
\hline \multirow{2}{*}{ Variable } & \multicolumn{3}{|c|}{ Quartile of dietary intake } & \multirow{2}{*}{$p$ for trend ${ }^{a}$} \\
\hline & $Q_{1}$ & $\mathrm{Q}_{2}$ & Q3 & \\
\hline \multicolumn{5}{|l|}{ Grain, g } \\
\hline Number of S/A & $16 / 10$ & $5 / 11$ & $6 / 11$ & \\
\hline Cut-off & $\leq 190.0$ & $190.0<$ to $\leq 279.9$ & $>279.9$ & 0.230 \\
\hline $\mathrm{OR}(95 \% \mathrm{CI})^{\mathrm{b}}$ & 1 & $0.281(0.07-1.21)$ & $0.377(0.08-1.81)$ & \\
\hline \multicolumn{5}{|l|}{ Potato, g } \\
\hline Number of S/A & $16 / 13$ & $3 / 8$ & $8 / 11$ & \\
\hline Cut-off & $\leq 0$ & $0<$ to $\leq 19.8$ & $>19.8$ & 0.565 \\
\hline OR $(95 \% \mathrm{CI})$ & 1 & $0.289(0.06-1.50)$ & $0.515(0.14-1.89)$ & \\
\hline \multicolumn{5}{|l|}{ Sweet, g } \\
\hline Number of S/A & $11 / 11$ & $14 / 11$ & $2 / 10$ & \\
\hline Cut-off & $\leq 5.5$ & $5.5<$ to $\leq 13.8$ & $>13.8$ & 0.094 \\
\hline OR $(95 \% \mathrm{CI})$ & 1 & $0.852(0.24-3.06)$ & $0.212(0.03-1.35)$ & \\
\hline \multicolumn{5}{|l|}{ Legume, g } \\
\hline Number of S/A & $8 / 12$ & $9 / 9$ & $10 / 11$ & \\
\hline Cut-off & $\leq 0$ & $0<$ to $\leq 20.0$ & $>20.0$ & 0.830 \\
\hline OR $(95 \% \mathrm{CI})$ & 1 & $1.489(0.37-60)$ & $0.998(0.25-3.94)$ & \\
\hline \multicolumn{5}{|l|}{ Fruit, g } \\
\hline Number of S/A & $10 / 10$ & $6 / 11$ & $11 / 11$ & \\
\hline Cut-off & $\leq 93.4$ & $93.4<$ to $\leq 211.7$ & $>211.7$ & 0.569 \\
\hline OR $(95 \% \mathrm{CI})$ & 1 & $0.463(0.11-1.94)$ & $0.632(0.19-2.7)$ & \\
\hline \multicolumn{5}{|l|}{ Meat, $g$} \\
\hline Number of S/A & $9 / 11$ & $7 / 10$ & $11 / 11$ & \\
\hline Cut-off & $\leq 0$ & $0<$ to $\leq 71.7$ & $>71.7$ & 0.554 \\
\hline OR $(95 \% \mathrm{CI})$ & 1 & $0.582(0.13-2.55)$ & $0.124(0.33-4.64)$ & \\
\hline \multicolumn{5}{|c|}{ Fish and seafood, g } \\
\hline Number of S/A & $11 / 10$ & $8 / 11$ & $8 / 11$ & \\
\hline Cut-off & $\leq 14 \cdot 5$ & $14.5<$ to $\leq 79.5$ & $>79.5$ & 0.839 \\
\hline OR $(95 \% \mathrm{CI})$ & 1 & $0.657(0.17-2.55)$ & $0.779(0.20-3.00)$ & \\
\hline \multicolumn{5}{|l|}{ Seaweed, g } \\
\hline Number of S/A & $12 / 14$ & $8 / 8$ & $7 / 10$ & \\
\hline Cut-off & $\leq 0$ & $0<$ to $\leq 3.0$ & $>3.0$ & 0.404 \\
\hline OR $(95 \% \mathrm{CI})$ & 1 & $1.265(0.33-4.90)$ & $0.531(0.13-2.21)$ & \\
\hline \multicolumn{5}{|l|}{ Dairy product, g } \\
\hline Number of S/A & $12 / 13$ & $5 / 8$ & $10 / 11$ & \\
\hline Cut-off & $\leq 0$ & $0<$ to $\leq 74.0$ & $>74.0$ & 1.000 \\
\hline OR $(95 \% \mathrm{CI})$ & 1 & $0.588(0.13-2.59)$ & $0.854(0.24-3.02)$ & \\
\hline \multicolumn{5}{|l|}{ Oil and seed, g } \\
\hline Number of S/A & $14 / 9$ & $7 / 12$ & $6 / 11$ & \\
\hline Cut-off & $\leq 6.5$ & $6.5<$ to $\leq 13.6$ & $>13.6$ & 0.109 \\
\hline OR $(95 \% \mathrm{CI})$ & 1 & $0.246(0.06-1.05)$ & $0.302(0.07-1.29)$ & \\
\hline \multicolumn{5}{|l|}{ Beverage, g } \\
\hline Number of S/A & $9 / 10$ & $5 / 11$ & $13 / 11$ & \\
\hline
\end{tabular}


Shin Y, et al. Cholecystectomic symptoms and diet

Supplementary Table 8. Continued

\begin{tabular}{|c|c|c|c|c|}
\hline \multirow{2}{*}{ Variable } & \multicolumn{3}{|c|}{ Quartile of dietary intake } & \multirow{2}{*}{$p$ for trend ${ }^{a}$} \\
\hline & Q1 & Q2 & Q3 & \\
\hline Cut-off & $\leq 1.0$ & $1.0<$ to $\leq 237.3$ & $>237.3$ & 0.598 \\
\hline OR $(95 \% \mathrm{CI})$ & 1 & $0.315(0.06-1.56)$ & $1.025(0.20-3.94)$ & \\
\hline \multicolumn{5}{|l|}{ Seasoning, g } \\
\hline Number of S/A & $12 / 10$ & $12 / 11$ & $3 / 11$ & \\
\hline Cut-off & $\leq 21.9$ & $21.9<$ to $\leq 42.0$ & $>42.0$ & 0.063 \\
\hline OR $(95 \% \mathrm{CI})$ & 1 & $1.037(0.29-3.74)$ & $0.179(0.03-1.06)$ & \\
\hline
\end{tabular}

S/A, symptomatic/asymptomatic; OR, odds ratio; CI, confidence interval.

${ }^{a}$ Estimates of $p$ values for a linear trend were based on linear scores derived from the medians of quartiles for intake of nutrients among asymptomatic.

${ }^{\mathrm{b}} \mathrm{OR}$ was adjusted for total energy, exercise frequency. 